Archived version from NCDOCKS Institutional Repository http://libres.uncg.edu/ir/asu/

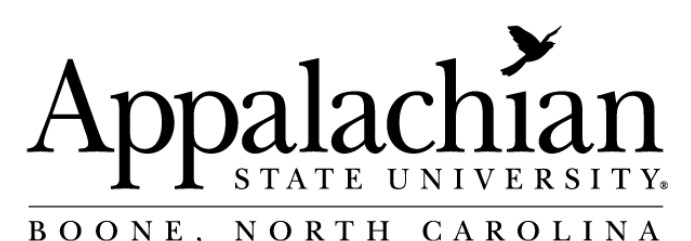

\title{
My Father Began Disappearing
}

By: Vicky Grube

No Abstract Available

Grube, Vicky (2012) "My father began disappearing". Visual Arts Research 38(1): 45-52 (summer 2012). Published by the University of Illinois Press (ISBN: 0221-8510). Version Of Record Available From www.muse.jhu.edu 


\section{MY FATHER BEGAN DISAPPEARING}

BY VICKY GRUBE
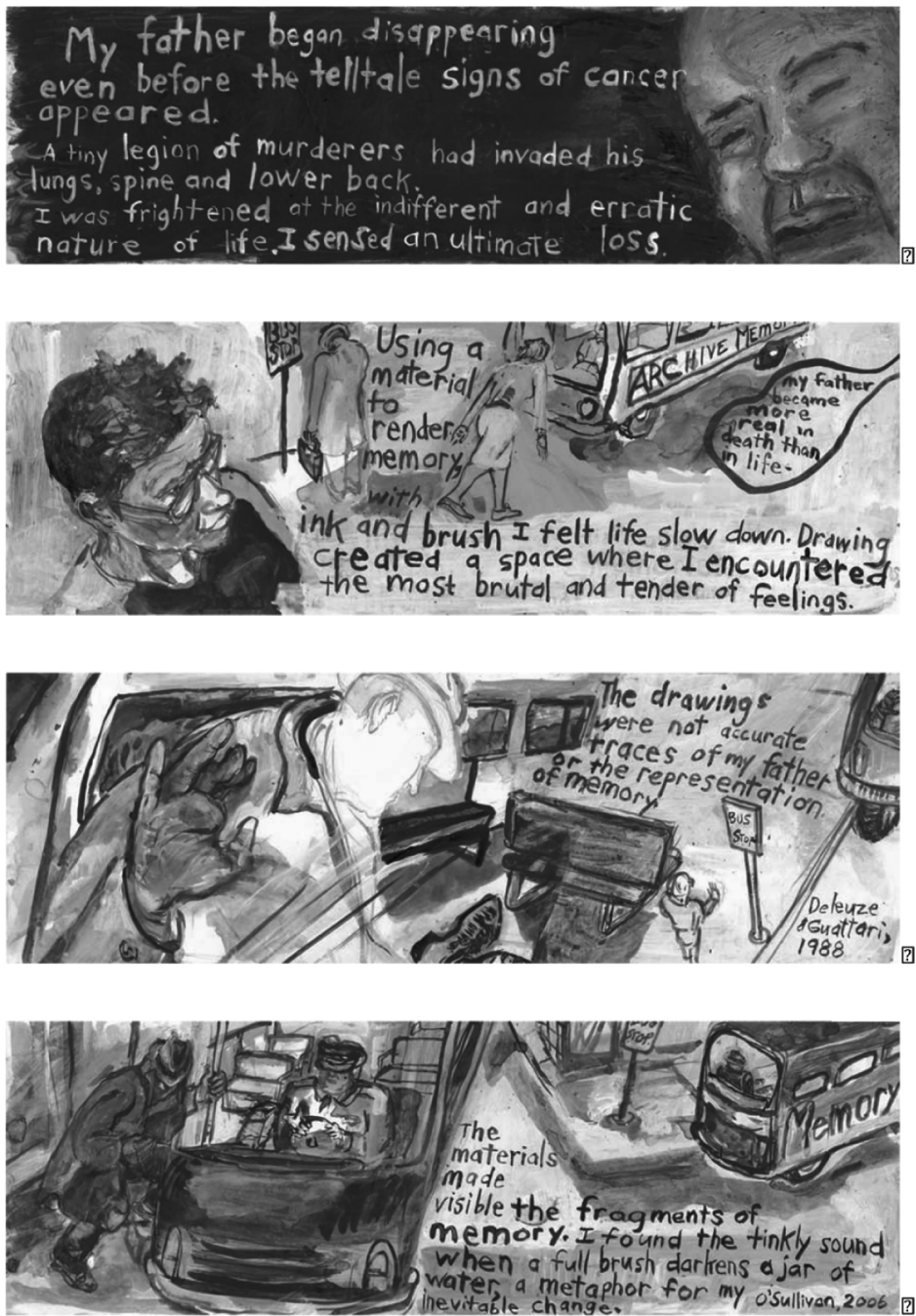

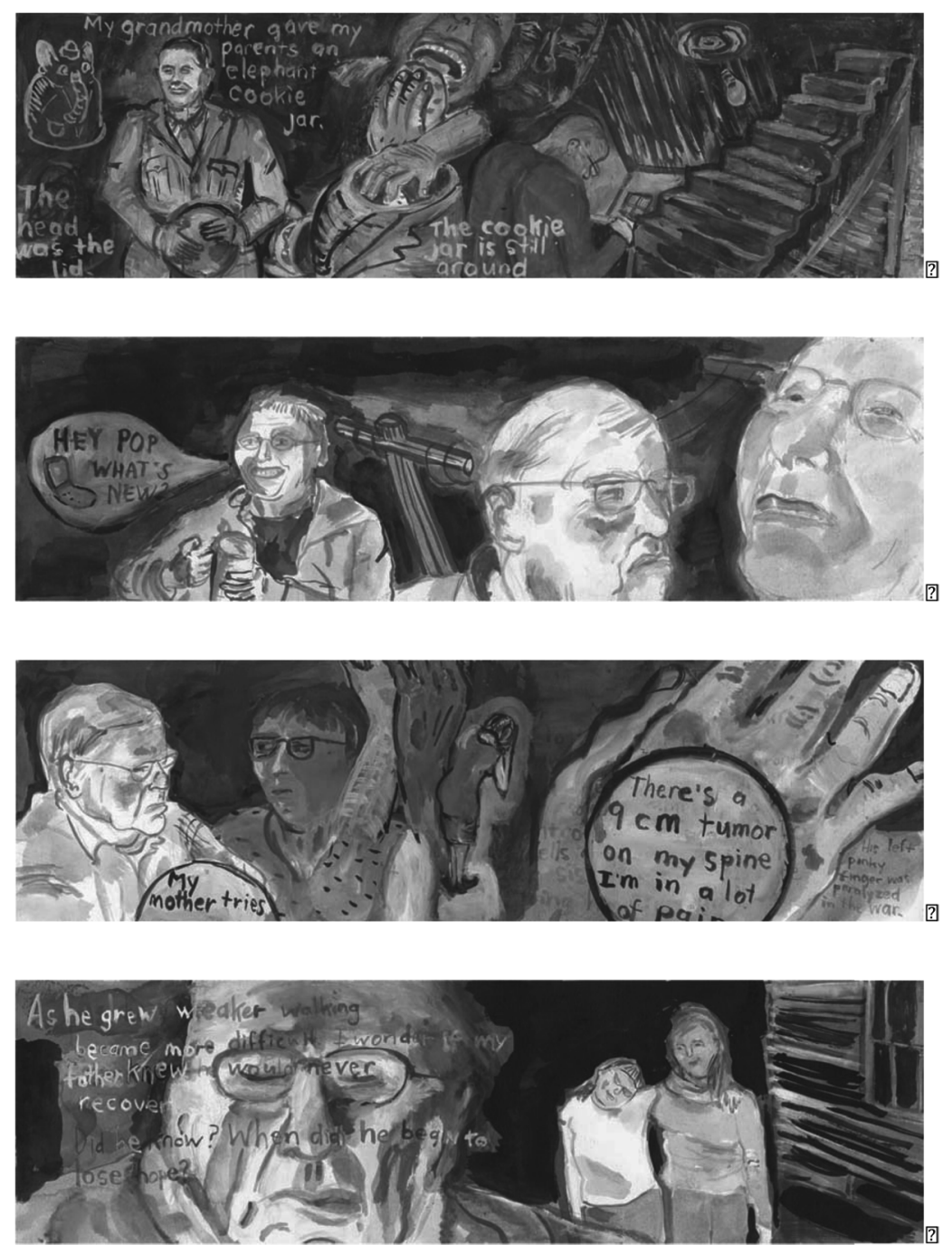

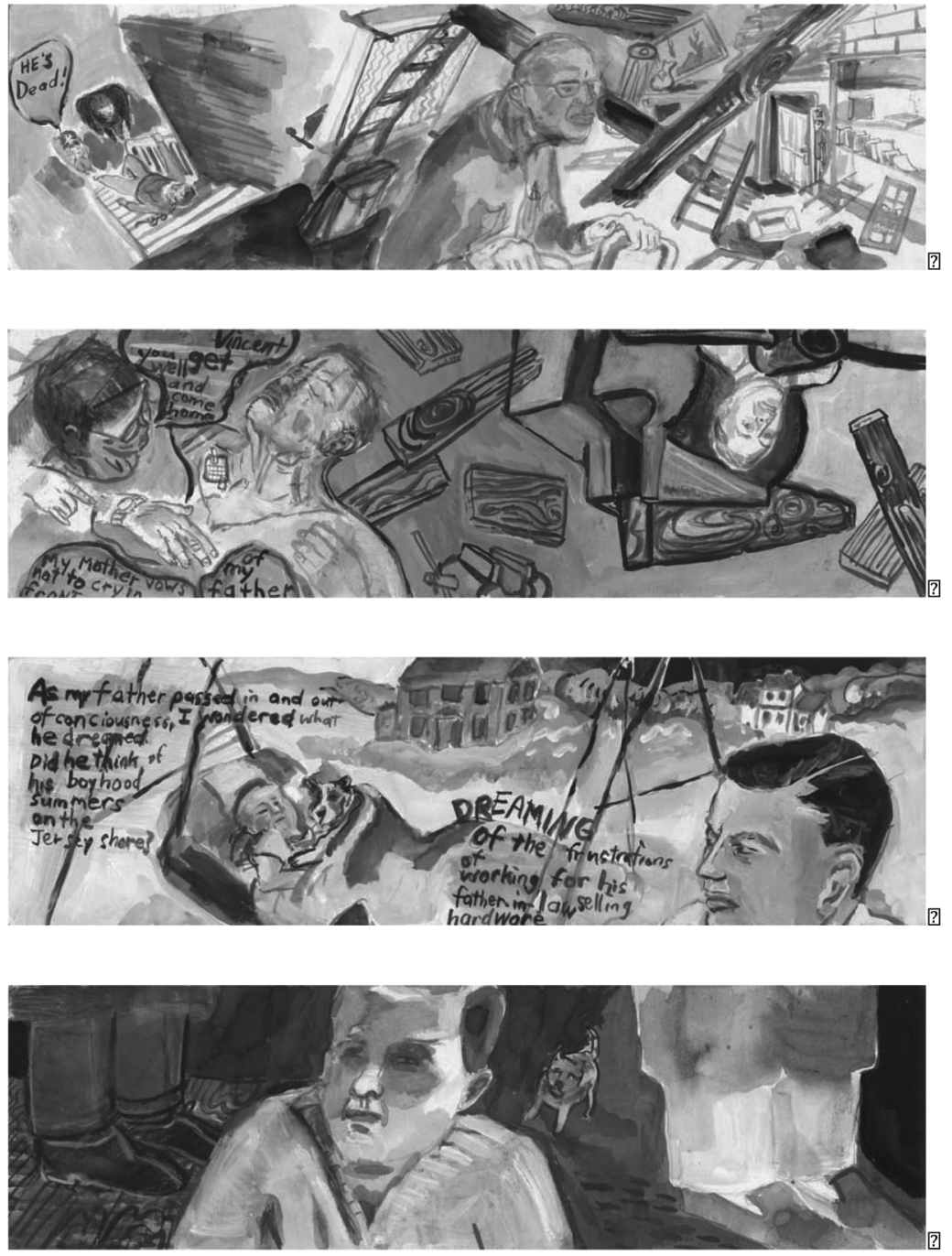

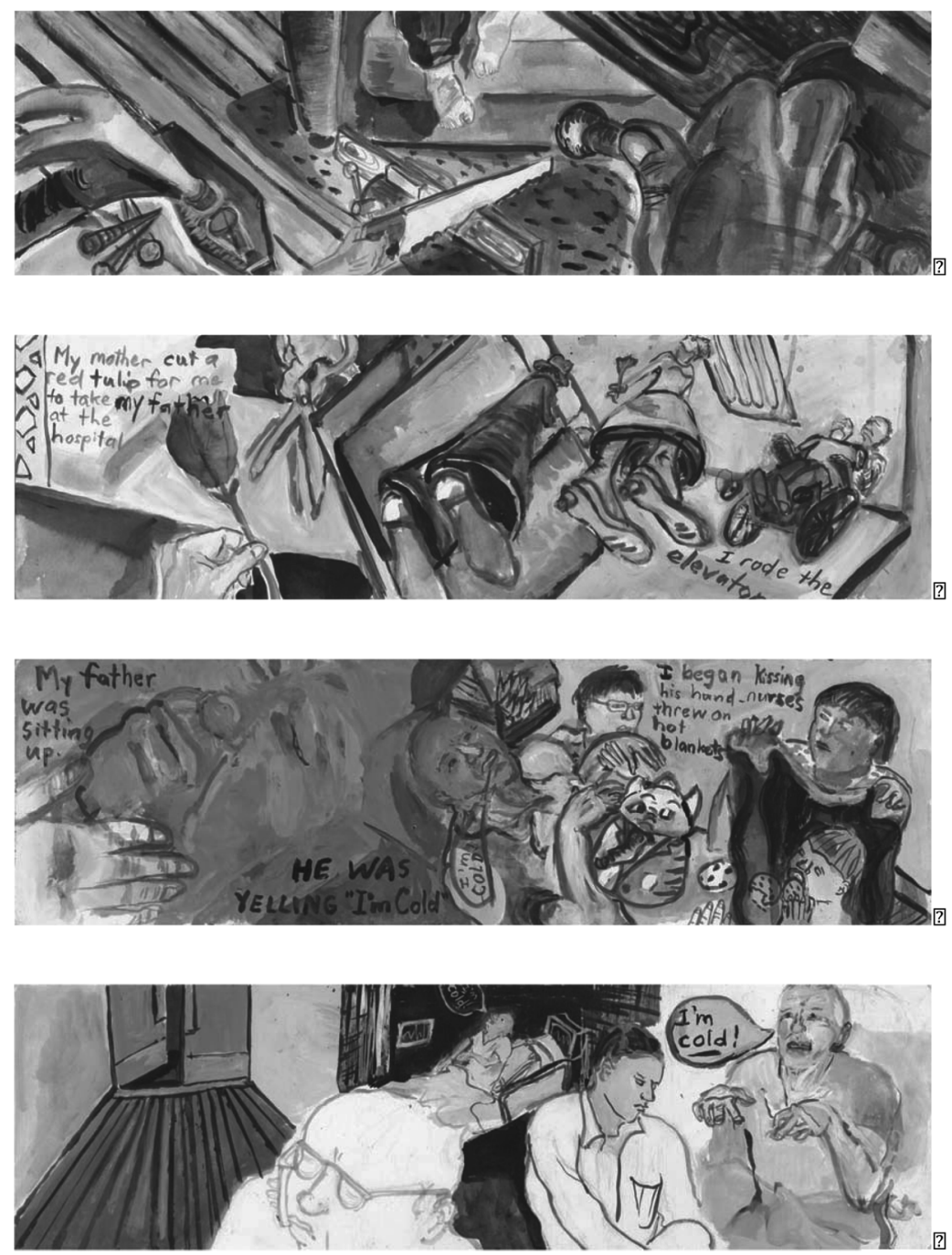

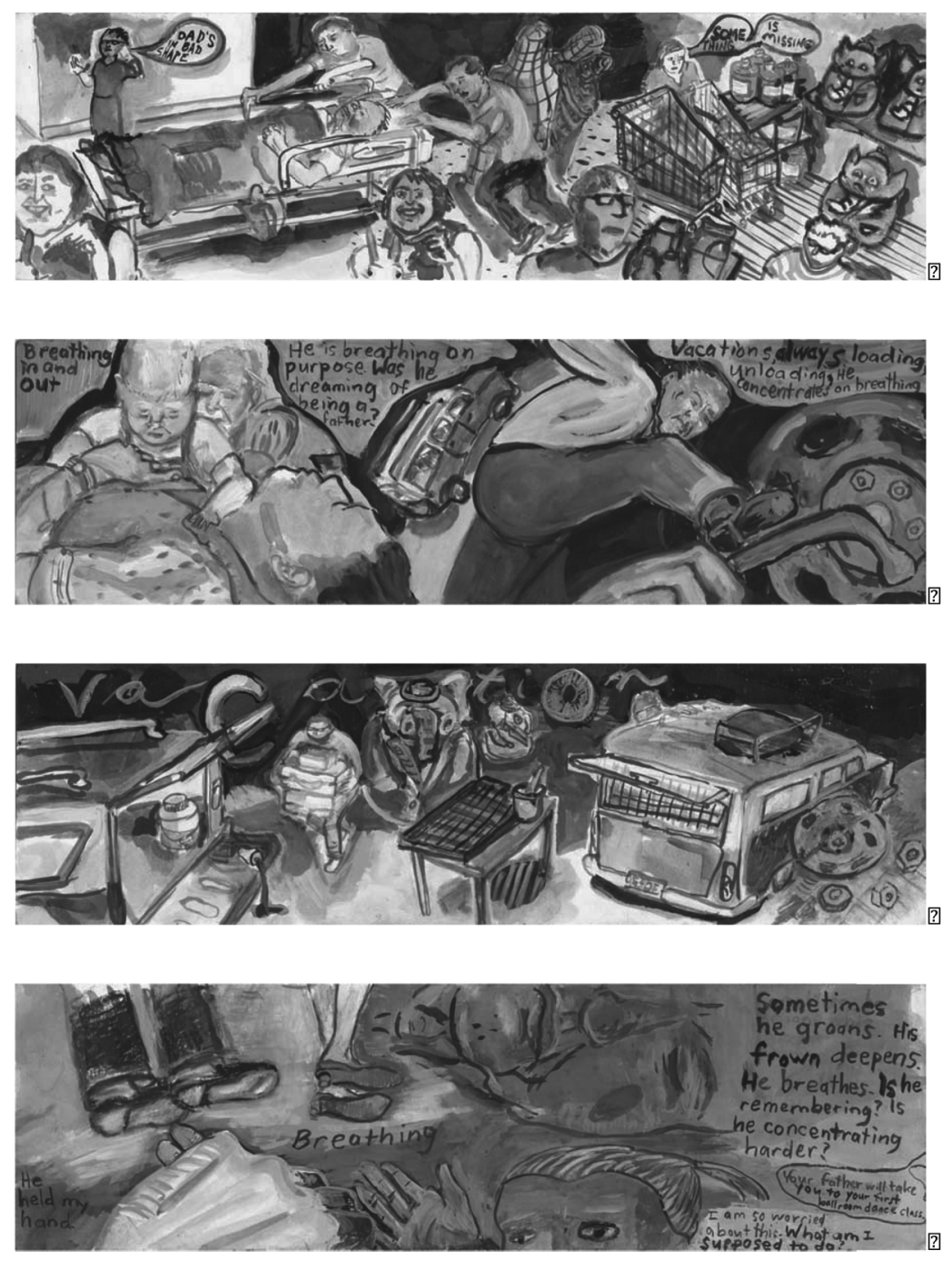

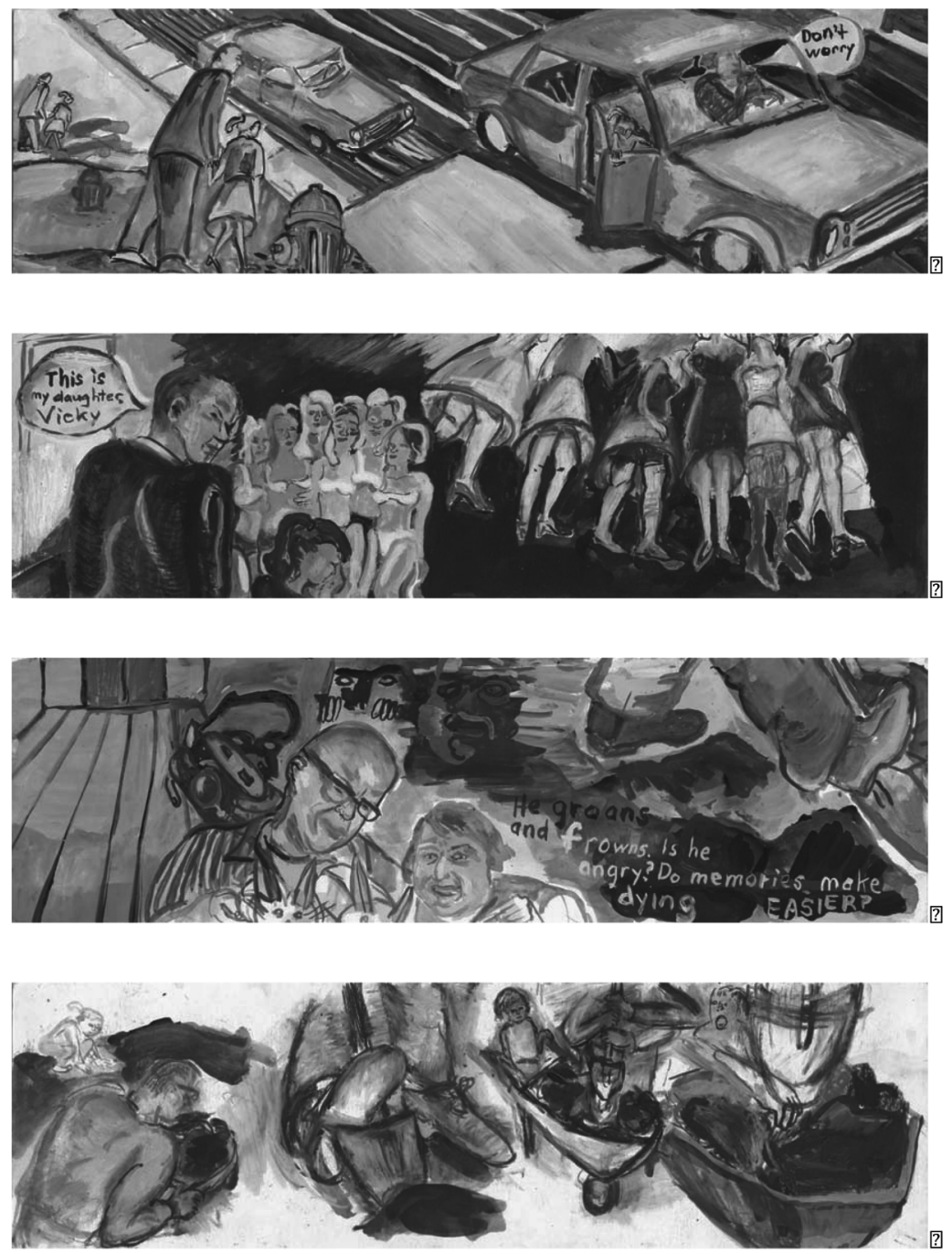

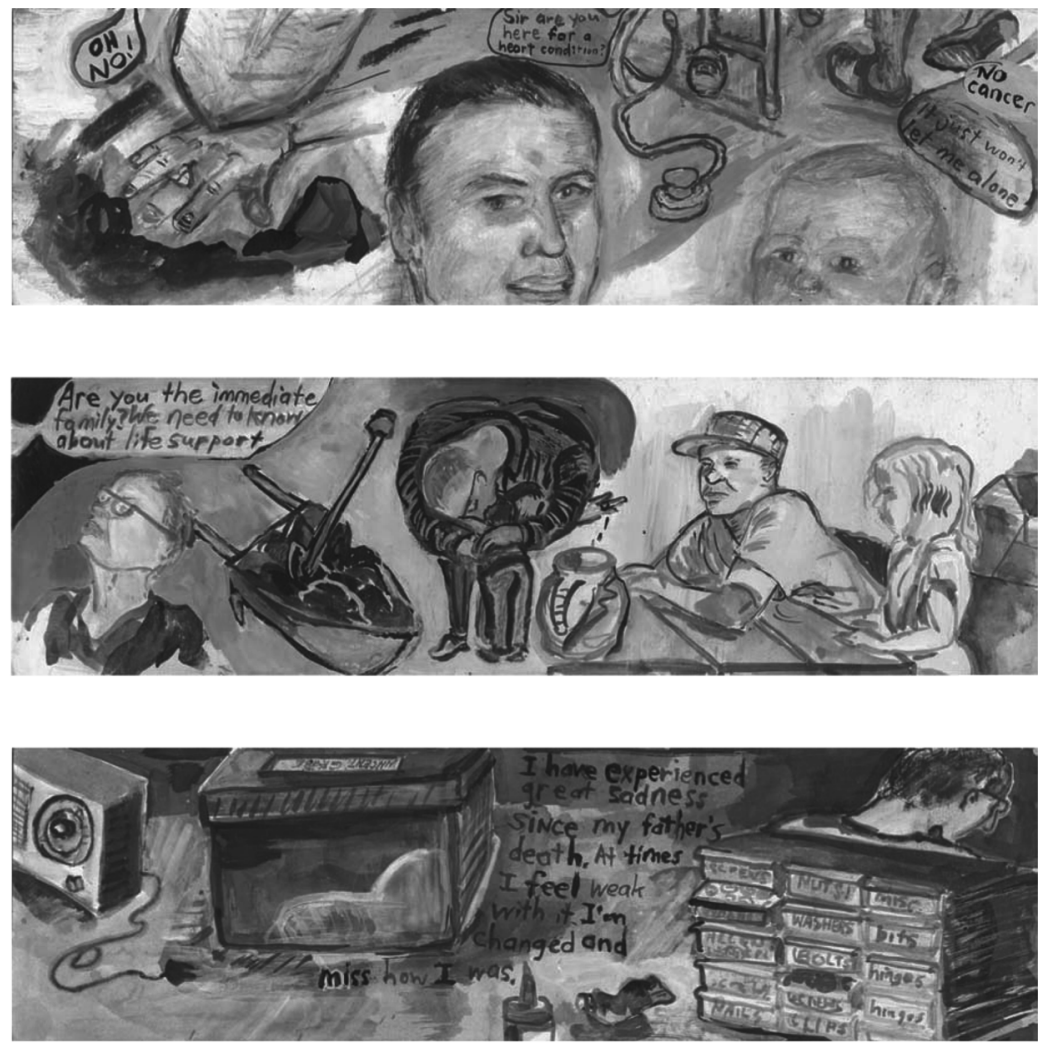


\section{REFERENCES}

BARRY, L. (2000). THE GREATEST OF MARLYS. SEATTLE: SASQUATCH BOOKS.

BROWN, J. (2002). BIGHEAD. CHICAGO: TOP SHELF PRODUCTIONS.

CHIPPENDALE, B. (2007). MAGGOTS. BROOKLYN, NY: PICTUREBOX PUBLISHING.

DAVIS,V. (2003). SPANIEL RAGE. OAKLAND,CA: BUENAVENTURA PRESS.

DERRIDA, J. (1996). ARCHIVE FEVER: A FREUDIAN IMPRESSION. CHICAGO: UNIVERSITY OF CHICAGO PRESS.

DERRIDA, J., BRAULT, P.A., \& NAAS, M. (2001). THE WORK OF MOURNING. CHICAGO: UNIVERSITY OF CHICAGO PRESS.

DELEUZE, G. \& GUATTARI, F. (1988). A THOUSAND PLATEAUS. LONDON: THE ATHLONE PRESS LTD.

GIPI (2006). THEY FOUND THE CAR. SINGAPORE: FANTAGRAPHICS BOOKS AND COCONINO PRESS.

O'SULLIVAN, S. (2006). ART ENCOUNTERS DELEUZE AND GUATTARI: THOUGHT BEYOND REPRESENTATION. BASINGSTOKE, UK: PALGRAVE MACMILLAN.

PORTER, R. (2009). DELEUZE AND GUATTARI: AESTHETICS AND POLITICS. CARDIFF: UNIVERSITY OF WALES PRESS. 